\title{
Methodological Approach to the Assessment of Neo-Industrial Export Specialization
}

\author{
Elena Andreeva*, and Alla Golovina \\ Ural State University of Economics, 620144 Ekaterinburg, Russia
}

\begin{abstract}
The relevance of the article is due to the importance of the development of export of high-processing industries. Objective: to develop methodological support for assessing the neo-industrial export specialization of regions and its determining factors. The research methods included identifying potential assessment parameters and testing their applicability based on the analysis of economic development statistics of the region selected as an example. The proposed methodological support for the assessment of neo-industrial export specialization includes its integral assessment, assessment of goods and services, assessment of the contribution of the high-tech component to the change in exports, ranking of regions by absolute values of high-tech exports. The method of assessing the factors of neo-industrial export specialization involves the assessment of indicators that identify these factors of exo-and endogenous order - the development of manufacturing production, innovation potential, transport potential, the development of the export support system, and the international demand for the region's products. The practical significance of the proposed methodological support lies in the fact that it makes it possible to analyze the neo-industrial export specialization of Russian regions and the factors of its development, and to identify and analyze possible directions of development in this area.
\end{abstract}

\section{Introduction}

The relevance of the topic is due to the importance for the economy of the country and its regions of creating high added value and generating income through its exports. Earlier, the study proposed a model for the development of neo-industrial export specialization (NES) in the region. It involves forming the specialization through the diversification and modernization of the production of goods. It also involves developing high-tech services sector and promoting high-tech small and medium-sized businesses. Moreover, the proposed model implies promotion of NES in the foreign market through the development of the region's image, overcoming gaps in the implementation of regional foreign trade and increasing the region's involvement in the system of world economic relations. Factors of NES development of endo - and exogenous nature were substantiated: the development of the manufacturing industry, innovation and labor potential, transport infrastructure, export support system of the region, the demand for regional products on the international market.

\footnotetext{
*Corresponding author: elenandr@mail.ru
} 
As a further step, it seems relevant to set a goal to develop methodology for the assessment of national regions and the factors that determine it.

Both NES and its factors are assessed in the scientific literature. In the first case, the high-tech specialization of the country's total export is considered and high-tech exports of the countries are compared [1, pp. 2780-2788]. In the other case, this specialization at the country level is assessed in a part of the selected sphere, for example, services: its scale and role in gross export are evaluated [2, p. 17-20]. Also the NES is estimated at the level of the country in the part of the chosen industry [3]. The existing methods of measuring the complexity of a country's export (its level of modernization) are analyzed [4, p. 6-8].

The NES factors include transport infrastructure, geographical location [3, p. 85]; the degree of participation of enterprises in foreign economic activity [1, p. 2783] and the maturity of commercial and financial networks, the factor of localization of companies [5, p. 248]; number of types of competitive goods [1, p. 2783]; degree of trade liberalization [1, p. $2783 ; 6$, p. 443] and export policy [5, p. 248]; human capital [6, p. 446]; inflow of foreign direct investments in manufacturing industries [6, p. 446; 7, p. 158]. The importance of the size of trade costs and demand as factors of the country's export growth is emphasized [8, p. 465], and in general, great importance is given to the global context [2, pp. 9-11]. It is also emphasised that the influence of factors is different for different sectors $[6$, p. 443, 446]. Such factor as the country's already existing share of manufacturing products in exports is also mentioned, but its debatability is emphasized [9, p. 4, 19].

In general, the analysis shows that the assessment of NES and its factors is carried out mainly on the scale of the country or a selected region. The development of methodological support for a comprehensive assessment remains relevant. This actualizes the purpose of the presented research.

\section{Materials and Methods}

Methodology for the process of developing a methodology for assessing NES regions and its determining factors was to identify (based on the analysis of the theoretical foundations of nes and its factors previously conducted in the course of the study) potential assessment parameters and verify their applicability based on the analysis of statistics and facts:

- on the socio-economic development of the region selected as an example. First of all, the indicators of production and export development were selected;

- $\quad$ on the international situation of demand for goods in the region, in order to assess the context of the export prospects of the region.

The following general scientific and economic methods were used to develop methodology for the assessment of NES regions and the factors determining it:

- method of constructing a simple and integral index, using operations of adding and dividing members, - when constructing indices of export specialisation of neoindustrial production of goods, services, integral index of NES;

- the method of export decomposition to identify the provision of incremental exports of the regions at the expense of incremental high-tech exports;

- statistical methods, in particular: work with arrays of numbers, in particular, the method of ranking regions by index values, by values of exports of high-tech goods and services; as well as dynamics analysis when analysing Russian exports of hightech services

- method of value gradation, when working with the values of the regions for each of the indices, in order to divide the values into values of different levels; 
- the method of complex typologisation which takes into account a number of parameters when constructing a typology of regions taking into account their values by a number of indices.

As information base for development of methodological support was taken statistics on the main socio-economic indicators, employment, production, first of all, manufacturing, innovation activity, foreign trade, transport infrastructure of Rosstat (rosstat.gov. ru), the Federal Customs Service and its Ural Department (utu.customs.ru), the Russian Export Centre, the Middle Urals Development Corporation, and the press, using the example of Sverdlovsk Region as an active industrial region involved in FEA, as well as statistics from other regions for comparison; and the United Nations Conference on Trade's global and country statistics (unctadstat.unctad.org/wds/TableViewer/dimView.aspx).

\section{Results and Discussions}

1. Based on the essence of the proposed model of its development, the methodology for assessing the development of regions involves the calculation of the following indices:

- The integrated index of the NES, which is calculated as the ratio of the sum of exports of high-tech goods and exports of technologies and services of a technical nature to gross exports of goods. As high-tech goods, the group of TN FEA is taken, which is fully represented by high-tech products - machinery, equipment and vehicles. In the Sverdlovsk region, the first component, exports of machinery, equipment and vehicles, in 2018 amounted to \$ 2.05 billion; exports of technologies and technical services $-\$ 14.9$ million, gross exports $-\$ 8.57$ billion. The Index was $24 \%$.

- The index of export specialisation of neo-industrial goods production will be calculated as the ratio of exports of high-tech goods to the volume of manufacturing production. It will show to what extent neo-industrial production of goods is export-oriented. Sverdlovsk average exports of machinery, equipment and vehicles 2013-2018 amounted to USD 1,433 million. The average volume of goods shipped in terms of machinery, vehicles and equipment, including electrical and electronic and optical equipment from 2013-2018 was USD 4,735 million. The index was $30 \%$.

- The index of export specialisation of neo-industrial service production will be calculated as the ratio of exports of technologies and services of a technical nature to the output of innovative goods, works and services. It will show to what extent neo-industrial production of services is export-oriented. For the Sverdlovsk Region, the second indicator in 2017 was $\$ 3,320$ million; the index was $0.36 \%$; in 2018 . $\$ 2,460$ million and $0.61 \%$.

- Identification of the change in regional exports due to changes in high-tech exports by the export decomposition method. In particular, we calculate how much of the increase or decrease in the region's exports was due to the increase or decrease in non-resource non-energy exports or high-tech exports. For example, the Sverdlovsk Region's exports in 2019 decreased by USD 1,230 million, while the decrease in exports of machinery, equipment and vehicles amounted to USD 774 million. Thus, the ratio of the change in exports of engineering products to the change in gross exports was $63 \%$, reflecting the importance of the contribution of engineering exports.

- The methodology suggests that the integral index is tested on the regions, and the regions are ranked according to it. The same approbation and ranking is envisaged for the indices of export specialisation of neo-industrial production; 
- The methodology also involves ranking regions by exports of high-tech goods and exports of high-tech services together and separately in order to compare regions by absolute value of this neo-industrial export. At the level of Russia as a whole, it is also intended to take exports of such high-tech services as educational and medical services and examine their dynamics.

- According to this set of parameters, the methodology involves building a comprehensive typology of regions, with the designation for each indicator of gradation: "low - medium - high", - which will allow to simultaneously take into account both the relative and absolute size of neo-industrial export of regions, both the neoindustrial orientation of their export and the export orientation of their neoindustrial production.

1. The analysis of the essence of the factors of the NES region allows us to propose a methodology for assessing the factors of the NES regions, which involves the allocation of indicators corresponding to these factors and indicators (indicator thresholds) reflecting the importance of this indicator for a particular region. Thus, the following indicators are proposed for the factors:

Endogenous factors:

Development of the manufacturing industry. Indicators:

- Volume of shipped products from the region's manufacturing industries. Thus, the Sverdlovsk Region has the 4th position, while the Chelyabinsk Region has the 6th position;

- Employment in the manufacturing industry. Thus, the Sverdlovsk Region has $20 \%$ of the employed in manufacturing; in the Urals Federal District, only the Chelyabinsk Region has a higher rate $(22.5 \%)$.

Availability of labour, intellectual and innovation potential. Indicators:

- Population density in the region (indirectly reflects the density of labour resources in the economy). For the Sverdlovsk Region it is 22.2 people $/ \mathrm{km} 2$.

- The share of employed population in the total population. The employment rate in Sverdlovsk Region is $57.8 \%$, the highest in the Urals Federal District is in the Yamal-Nenets Autonomous District (YNAO) (74.5\%).

- the ratio of university and higher education graduates to the total population;

- the ratio of innovative products to the total volume of manufactured goods shipped. The first indicator in the Sverdlovsk Region was RUB 154 billion in 2018, the second was RUB 1,969 billion; the ratio is $7.8 \%$.

Availability of technological development prospects. Indicators:

- Number of universities and scientific organisations and the number of branches, including both research units at universities and the availability of research institutes. Thus, in the Greater Urals and the Urals Federal District, apart from Ural Federal University, universities in other regions (e.g. Chelyabinsk, Perm) also have the status of research universities; the Urals Branch of the Russian Academy of Sciences has 25 research organizations in Ekaterinburg according to the Ural branch of the Russian Academy of Sciences website.

- The enterprises carry out their own research $(R \& D)$. Indicators such as the number of organisations in the region carrying out innovative activities (in the Sverdlovsk region in 2019 - 318), or the level of innovation activity of organisations (11.6\%) can be used here.

Transport development:

- Availability and number of transport hubs, hubs, terminals and ports. For example, Ekaterinburg has seven railway lines and six federal highways (investural.com), as well as an international airport. 
- density and quality of railways. The Sverdlovsk Region ranks second in the Urals Federal District in density of railways after the Chelyabinsk Region $(203 \mathrm{~km} \mathrm{/}$ $10,000 \mathrm{~km} 2$ ), ahead of such regions as the Nizhny Novgorod, Novosibirsk, Omsk, Republic of Tatarstan and Perm Krai. However, it is inferior to Tatarstan and Perm Territory in terms of road density $(126 \mathrm{~km} / 10,000 \mathrm{~km} 2)$.

Exogenous factors:

- The demand for the products of the industries represented in the region on the international market (technological demands of the international market). The volume of demand for certain products of the region on the world market, in neighbouring countries, can be considered as an indicator. In the case of the Sverdlovsk region, this is, for example, railway cars (so, in 2017, 15 thousand were produced (TASS. 26.12.2017)), in the case of the Chelyabinsk region - selfpropelled road construction and agricultural machinery (in the first half of 2018, 816 machines were produced (AiF. 19.07.2018)). Thus, global imports of railway vehicles and equipment in 2019 amounted to USD $26.7 \mathrm{bn}$. (2016 saw a decline to 23.1); Belarus imports of $\$ 243$ million; Kazakhstan imports of $\$ 500.6$ million; China imports of $\$ 1,031$; Mongolia imports of $\$ 9.1$ million. (United Nations Conference on Trade).

- The international demand for the region's innovative products in the long term. The demand for products of the "future" produced in the region can be analysed here. For example, the Catalogue of Innovative Products of High-Tech Enterprises of the Sverdlovsk Ministry of Industry and Science and the High-Tech Technopark includes (computer numerical control) CNC machines, including metal-cutting machines. Global imports of metal-cutting equipment have been fluctuating in recent years (rising from 2016 to $\$ 22.0$ billion in 2019), but overall, from 1995 to 2002 , they have increased from $\$ 9.1$ billion to $\$ 12.2$ billion. Import peaks in Russia's neighbouring countries in previous years illustrate their demand potential: Belarus peaked 3.6 times in 2014, Mongolia 4.9 times in 2019, Kazakhstan 1.5 times in 2015 and China 1.5 times in 2019 (United Nations Conference on Trade).

Development of transport infrastructure in the region's district, in neighbouring regions, including to the border with foreign countries. Indicators:

- federal transport highways passing through the region, their number and orientation. For example, national transport highways pass through the Sverdlovsk Region, leading to consumers in Europe and Asia. However, the north of the Sverdlovsk Region is remote in relation to these routes;

- proximity to seaports. The availability of a port or the distance from the administrative centre of the region to the nearest port may be taken into account here;

- proximity to foreign countries: whether the region is a border region, or to the border.

Development of the export support system, including for high-tech exports: the availability and nature of support measures that stimulate high-tech production in the region, taking into account the industries (sectors) and types of enterprises represented in the region. Here indicators of the presence of an export support centre and other structures in the region, and of an export catalogue can be taken into account. Thus, according to the Russian Export Centre, export support centres function in 29 regions. At the selective comparison the number of the enterprises of the region which have received support to export, on various kinds of support can be taken into account: visiting business missions, support to participation in the international exhibitions, accommodation on the international electronic trading platforms, reception of foreign delegations, search of the partner, training, acceleration of export projects. 
Competition on the international market for the region's high-tech product lines: determining the volume of international consumption and production and comparing them to identify the likelihood of pro- or shortages. For example, in the pharmaceutical industry, especially against the backdrop of the pandemic, production of substances has declined, leading to shortages. Although China had already begun to cut back two years earlier amid environmental reforms (kommersant.ru/doc/4329331).

Indicators or indicator thresholds reflecting the importance of a given indicator for the regions will be the criteria for the degree and nature of the regions' NES, This degree will be revealed by comparing the indicator with the value of the selected region. A gradation can be assumed for indicators, which will allow for a more complex, diversified representation of the nature of the NES regions. Indicators can be calculated on the basis of minimum and maximum values within the entire set of regions.

\section{Conclusions}

The analysis of statistics and factors on the example of the selected region showed the applicability of the proposed assessment parameters. The proposed methodology for assessing neo-industrial export specialization includes integral assessment of the NES region, assessment of export specialization by goods and assessment by services, assessment of the contribution of high-tech component to export change, ranking of regions by absolute values of high-tech export. The methodology for assessing NES factors implies the evaluation of indicators that identify these factors of exogenous and endogenous order: development of manufacturing production, innovation potential, transport potential, development of export support system, international demand for the region's products. The practical significance of the proposed methodology lies in the fact that it makes it possible to analyze the NES of the Russian regions and factors of its development, and to identify and analyze possible directions of development in this area.

\section{Acknowledgment}

The publication was prepared with the financial support of the Russian Fundamental Research Fund within the framework of the research project No. 20-010-00806-A.

\section{References}

1. L. Teslyuk, N.V. Dukmasova, Yu.V. Plastinina, M.E. Shamsudinov, Economic relations, 9, 2773 (2019)

2. A. N. Spartak, Russian Foreign Economic Bulletin, 12, 7 (2018)

3. S.V. Rimkevich, Russian Foreign Economic Bulletin, 10, 82 (2018)

4. N. Chrid, S. Saafi, M. Chakroun, J Knowl Econ, 18, 1 (2020)

5. E. Andreeva, E. Sapir, I. Karachev, D. Zherenkov, SGEM(Book 2), 5, 245 (2016)

6. C. Henn, C. Papageorgiou, J.M. Romero et al., IMF Econ Rev, 68, 421 (2020)

7. G.M. Aubakirova, Problems of forecasting, 1(178), 155 (2020)

8. V. Pinilla, A. Rayes, Cliometrica,13, 443 (2019)

9. C.A. Carrasco, E.D. Tovar-García,Econ Change Restruct, 3rd Aug, 1 (2020) 